\title{
English teacher training programs focused on reflection
}

\author{
Yamith José Fandiño-Parra
}

Magíster en docencia. Docente,

Universidad de La Salle, Facultad de

Ciencias de la Educación, Bogotá,

Colombia.

yfandino@unisalle.edu.co

\section{Abstract}

There is an evident need for teacher training programs in English as a foreign language, particularly ones that respond to the professional interests and needs of student teachers and teacher trainers. The primary objective is to propose reflection and questioning as a strategy to help teacher training programs in English as a foreign language go from simply implementing or transplanting models or concepts to generating practices that make it possible to build know-how based on and concerning the teacher's own reality. Documental research is the method used. Goals, guidelines, principles and focuses are proposed to create sound university programs in teaching English as a foreign language.

\section{Key words}

Higher education, foreign language teaching, normal school, English as a foreign language, training models. (Source: Unesco Thesaurus).

Recepción: 2011-05-11 | Aceptación: 2011-07-16

ISSN 0123-1294 | Educ.Educ. Vol. 14, No.2 | Mayo-agosto de 2011 | pp. 269-285 


\section{Programas de formación de docentes de inglés centrados en la reflexión}

Resumen

Se evidencia la necesidad de programas de formación docente en inglés como lengua extranjera, que respondan a los intereses y las necesidades profesionales de los estudiantes-profesores y los formadores de profesores.

El objetivo principal es proponer la reflexión y el cuestionamiento como estrategia para que los programas de formación docente en inglés como lengua extranjera pasen de simplemente implementar o trasplantar modelos o conceptos, a generar prácticas que permitan construir conocimientos de y en sus propias realidades. El método utilizado es la investigación documental.

Se concluye proponiendo metas, guías, principios y focos para la creación de sólidos programas universitarios en la enseñanza del inglés como lengua extranjera.

\section{Palabras clave}

Educación superior, enseñanza de lenguas extranjeras, escuela de profesores, inglés como lengua extranjera, modelos de formación (fuente: Tesauro de la Unesco).

\section{Programas de formação para professores de inglês baseados na reflexão}

\section{Resumo}

Há uma clara necessidade de estabelecer programas de formação de professores em inglês como língua estrangeira, para responder aos interesses e as necessidades profissionais dos alunos-professores e formadores de professores.

O objetivo principal é propor a reflexão e o questionamento como estratégia para os programas de formação docente em inglês como língua estrangeira passar simplemente de implementação ou transplante de modelos ou conceitosa gerar práticas para criar conhecimento de suas próprias realidades em estas.

O método utilizado é a pesquisa documental.

Conclui propondo metas, diretrizes, princípios e focos para a criação de fortes programas universitários no ensino de inglês como língua estrangeira.

\section{Palavras-chave}

Ensino superior, ensino de línguas estrangeiras, escola de professores, inglês como língua estrangeira, modelos de formação (Fonte: Thesaurus UNESCO). 
Asking "what and why" questions gives us a certain power over our teaching. We could claim that the degree of autonomy and responsibility we have in our work as teachers is determined by the level of control we can exercise over our actions. In reflecting on the above kind of questions, we begin to exercise control and open up the possibility of transforming our everyday classroom life. (Bartlett, 1990, p. 267 as cited in Richards, 1991).

\section{Introduction}

Agray (2008) says the expectations Colombian society has concerning the foreign language $(\mathrm{FL})$ teacher are based mostly on instrumental demands, because people want $\mathrm{FL}$ teachers to be able to teach them what they need to know, using a fast, easy, effective, and cheap method that does not imply a lot of time, study, or discipline. For their part, asserts Agray, the Colombian State and universities conceive the role of FL teachers in terms of quality practices, social responsibility and critical research. Concretely, the State and universities contend the FL teacher should be a professional in foreign languages, pedagogy, and research and demonstrate critical, reflective and ethical behavior, as well as commitment. In spite of this, Agray maintains there is a divorce between what the law establishes and the actions to make it happen. In other words, the official discourse about FL teaching seems to favor quality, research, and responsibility, but the everyday reality of FL classrooms reveals a disarticulation of actions and a lack of resources. That is why, Agray asserts, FL teachers, as professionals and subjects, should be the ones in charge of answering for what society asks, not just to fulfill its external demands, but also to satisfy their own internal needs.

Unfortunately, according to Shohamy (2006), most FL policies, educational reforms, and government regulations are imposed and manipulated without attention to the needs and wishes of those who are either affected by them or expected to carry them out. Through a variety of overt and covert mechanisms used by those in authority, states Shohamy, languages are manipulated and controlled so as to affect, create, and perpetuate not only the "correct" (pure, native-like, grammatical) use, but also group membership ("us/them"), inclusion or exclusion, loyalty or patriotism, economic status ("haves/have nots"), and classification of people. In a similar vein, Ricento (2006) claims language-policy debates are always about more than language. To him, ideologies about language in general, and specific languages in particular, have real effects on language practices and largely delimit what is and what is not possible in the realm of language planning and policy-making.

In this regard, González (2009) says the spread of the ICELT (In-service Certificate in English Language Teaching) and the TKT (Teaching Knowledge Test) in Colombia plays a clear role in the homogenization, businessification and inequality of EFL policies, reforms, and regulations in Colombia. To her, "Bilingual Colombia" as a language policy has brought about regulations on various aspects of language learning and teaching, such as desired standards, teachers' qualifications and professional development. These regulations, explains González, reveal (a) a traditional view of native speakers and their supremacy and ownership in use of the language, (b) a lack of analysis of the linguistic situation of Colombia as a country placed in the expanding circle of World Englishes, and (c) little discussion on the growing role of non-native-speaker teachers in the TESOL profession. González argues the professional development model proposed in 2007 as part of "Colombia Bilingüe" is a representation of colonial, traditional, and central discourses in ELT that needs to be reshaped in light of the new, local, and peripheral knowledge constructed by Colombian ELT scholars and teachers.

Therefore, it seems new EFL teacher education programs (TEPS) are needed if they are to satisfy not only the expectations that Colombia's society has of its EFL teachers, but also to respond to the professional interests and needs of EFL student teachers (STs) and teacher educators (TEs). This paper argues for regarding reflective teaching as a valid option to allow EFL TEPs to move from merely implementing or transplanting im- 
posed models or concepts to generating opportunities to construct knowledge based on and in their own practices and realities. First of all, a brief overview of EFL TEPS in Colombia will be provided. Then, some key concepts about teacher education will be discussed succinctly. Next, EFL teacher education will be presented as a long-term process aimed at promoting and integrating distinctive but complementary domains and models. After that, some useful elements and suggestions based on reflective teaching will be put forth as suitable alternatives for new and improved EFL university programs. Then, inquiry will be proposed as a fundamental principle for EFL TEPs in Colombia. Finally, a basic description of what new EFLTEPs should have and do will be offered.

\section{EFL Teacher Education Programs in Colombia}

Most Colombian universities offering EFL TEPs claim research and reflection are key elements in the formation of pre-service language teachers. The Universidad Nacional de Colombia, for example, states its objectives, among others, are: "Reflexionar sobre aspectos de la lengua, su pedagogía, su cultura" and "impulsar cambios a través de la investigación y el diario quehacer como educador". Similarly, Universidad del Valle maintains that one of its main objectives is: "Desarrollar en el estudiante competencias investigativas que le permitan indagar, reflexionar y discutir sobre problemas relacionados con la descripción pedagógica de las lenguas extranjeras y las áreas disciplinarias". Along a similar line, the Universidad de Antioquia says one of its core elements is research, since "...la investigación [...] propicia una actitud crítico-reflexiva propia de la investigación pedagógica".

These objectives seem to suggest a strong commitment on the part of Colombian universities to engaging in reflection and research at every moment or stage of their formative programs. However, when reviewing the courses of study at 20 universities,' one sees most of them offer their pre-service teachers just three research-based academic spaces. These spaces usually appear around the fifth, sixth, and seventh semesters as preparation for the teaching practicum and in advan-

1 This review is based on the information made available by the universities on their websites with respect to their EFL TEPs. ce of two thesis seminars. Only four universities (Universidad Distrital de Bogotá, Universidad Pedagógica Nacional and Technological University of Colombia and Universidad de La Salle) seem to provide their pre-service teachers with more than five academic spaces devoted to research and/or reflective teaching, in addition to teaching practicum and thesis seminars. Apart from being more numerous, these academic spaces tend to start in the early semesters of the pre-service teachers' formative process, which may have a positive impact on their teaching training because, as Burns (2005) states, student teachers and teacher educators should be engaged as much as possible in developing their own theories of teaching, gaining more understanding of classroom decision-making, and using strategies for critical self-awareness and selfevaluation.

On the other hand, a review of 10 Colombian academic articles and research studies on reflection and research ${ }^{2}$ seems to indicate that work with reflective teaching and action research is linked closely to either pre-service teachers' practicum or in-service teachers' professional development. Zambrano and Insuasty (2009), for example, indicate student-teachers demonstrate they gain significant insights when they enhance features such as evaluating and analyzing their teaching experience critically, identifying and solving problems, discussing their teaching with others, and improving classroom processes. Similarly, Muñoz, Quintero and Munévar (2002) claim that a research-action-reflection approach to practicum helps pre-service teachers to recognize the meaning of the educational profession, to transform their own practice, and to strengthen the coherence between thinking and doing. For their part, Vergara, Hernández,

2 This review is based on reflective and research articles published during the last 10 years by long-standing and well-known Colombian journals: PROFILE (Universidad Nacional de Colombia), ÍKALA (Universidad de Antioquia), CAL (Universidad Distrtital de Bogotá), and EDUCACIÓNY EDUCADORES (Universidad de La Sabana). 
and Cárdenas (2009) maintain the study of classrooms done by in-service teachers helps in the development of learning and teaching theories, which ultimately paves the way for them to move from being mere consumers to generators of knowledge. Furthermore, Erazo-Jiménez (2009) view reflexive practice as professional metacompetence that is the basis for updating, furthering and mobilizing the professional knowledge of in-service teachers. Also, she asserts that it can work as a strategic way to reinforce the quality of education.

Undoubtedly, Colombian universities and EFL TEPS have strived to make research and reflection part of their course of studies for both pre-service and in-service teachers. However, this endeavor may have not been enough. As Calvo, Rendón and Rojas (2004) claim, most efforts have been the result of national laws and regulations that may not account for what is really happening inside the teacher education units. These efforts, argue Calvo et al., may have been obstructed by the permanence of traditional pedagogical models that privilege technical training, which goes against theoretical, pedagogical, and curricular innovation and restructuring promoted by research and reflection. Additionally, they point out that, although there have been several proposals to strengthen reflection and research in teacher education and development, the articulation between the teaching-learning model of the institutions and their real possibilities for better formative processes has not been proven. In a similar vein, Caicedo (2008) says TEPs need to be reconsidered, so they can implement new curriculum approaches to form educators who are able, among other things, (a) to develop critical and creative thinking, (b) to do and communicate research properly, and (c) to face today's challenges holistically.

This brief overview of the Colombian context seems to suggest Colombian EFL TEPs need to analyze how research is carried out in their study courses and, more specifically, how a reflective teaching-learning philosophy can be infused into all their academic spaces and formative processes. Colombian TEPs should move from regarding reflection as a simple strategy to improve pre-service teachers' practicum and in-service teachers' development to integrating it into all their teaching and learning practices. Reflective teaching should, therefore, be considered as a fundamental appro- ach to observing, criticizing and transforming teacher education, and ultimately, improving the quality of education. The next section discusses teacher education in some detail.

\section{Teacher Education}

UNESCO (1990) declares that teacher education refers to both pre-service and in-service programs that adopt both formal and/or non-formal approaches in a continuing process focused on teacher career development. In this respect, Villegas-Reimers (2002) defines teacher education as a long-term process that includes regular opportunities and experiences planned systematically to promote growth and development in the profession. To Cochran-Smith and Zeichner (2009), teacher education or teacher preparation is conducted in local communities and institutions where program components and structures interact with one another as well as with the different experiences and abilities teachers have and the local and political conditions states impose. In a similar vein, Loughran (2006) says teacher education has two important foci: learning about teaching and teaching about teaching, each of which involves complex skills, knowledge, abilities, and competences. These foci, in turn, are further complicated by the competing cognitive and affective tensions that influence learning and growth through experiences in the practice setting.

When discussing teacher education, FeimanNemser (1990) talks about five different theoretical positions concerning the goals, the means and the ends of teacher preparation. These are conceptual orientations that reflect distinct program emphases. In her opinion, these theoretical positions highlight different issues that must be considered in teacher education, but she clarifies that none offers a fully developed framework to guide program development. The five conceptual orientations are: (a) personal orientation, which affords primary attention to the teacher as person and learner, and suggests that personal development 
is a precondition of teaching; (b) critical orientation, which focuses on the habit of questioning assumptions about teaching, learning and knowledge that are taken for granted and highlights the teacher's responsibility to create classrooms that reflect democratic principles; (c)technological orientation, which stresses scientific knowledge and systematic training; (d) practical orientation, which places emphasis on the "wisdom of practice" and learning from experience; and (e) academic orientation, which not only emphasizes the teacher's role as an intellectual leader and a subject matter specialist, but also highlights the importance of knowing how to transmit knowledge and to develop understanding successfully.

In the twenty-first century, teacher education, both initial preparation and ongoing development, is in a time of transformation and challenge. According to Adler (2004), this is because schools today are expected to ensure all students learn and perform at high levels. However, schools are increasingly filled with a more varied population that brings diverse cultural backgrounds to its learning, as well as a range of cognitive styles and socioeconomic challenges. Teacher education is, thus, expected not just to help teachers to know content well, but more importantly to be masters of a variety of teaching strategies, and to be able to assess learners and to adjust teaching appropriately and in a timely fashion. As a result, argues Adler, teacher education confronts an array of difficult questions such as: "How should teachers be prepared for the challenges they face? Should teachers be able to think critically about "real world" problems and technical skills? Or, Should the focus be on the nature of thinking and the work of schools? These questions, in turn, force university programs to reexamine the goals and processes of teacher education.

Unfortunately, according to Vieira and Moreira (2008), despite the reform movements, teacher education still tends to tell teachers what and how to do things (technical instruction) rather than facilitating a thorough understanding of and a purposeful intervention in educational contexts (reflective inquiry). To them, this state of affairs raises constrains on reflectivity, authenticity, dialogical interaction, openness to innovation and autonomy. If STs and TEs are to become critical agents, claim Vieira and Moreira, they should not only become critical consumers and creative users of knowledge, but also informed participants in the improvement of the educational situations they experience. For its part, EFL teacher education has its own specifications, some of which will be discussed next.

\section{EFL Teacher Education Programs}

According to Johnson (2009), the way L2 teachers are prepared has been influenced by several trends that have reconceptualized how people think about L2 teachers, L2 teacher learning, and L2 teaching. In her opinion, these trends have been fueled by shifting epistemological perspectives on learning in general, and on L2 learning and L2 teacher learning in particular; perspectives that ranged from behaviorism and cognitivism to situated, social, and distributed views of human cognition. As a result, EFL teacher education has shifted from simply taking disciplinary knowledge about learning and second language acquisition and applying it to the language classroom to conceptualizing $L 2$ teachers as users and creators of legitimate forms of knowledge who make decisions about how best to teach their L2 students within complex socially, culturally, and historically situated contexts. In other words, explains Johnson, L2 teacher education should no longer view L2 teaching as translating theories into effective instructional practices, but as a dialogic process of co-constructing knowledge that emerges out of particular sociocultural practices and contexts.

In this regard, Richards (1998) claims there is no consensus on what the essential conceptual foundations of EFL teacher education are. Yet, in an effort to determine appropriate curricular content and effective instructional processes, he proposes six domains as the core knowledge base of EFL TEPs: theories of teaching (theoretical bases for the approach to teaching as well as instructional practices), teaching skills (essential dimensions of the repertoire of any teacher), communication skills (competence in language proficiency and information exchange), subject matter knowled- 
ge (specialized disciplinary knowledge of FL teaching), pedagogical reasoning and decision-making (complex cognitive and problem-solving skills underlying teaching practices), and contextual knowledge (information about educational and linguistic policies as well as familiarity with students, institutions, and programs). The development of these domains in EFL TEPs, contends Richards, can help STs and TEs to understand the bases of their classroom realities and to improve their educational experiences, which ultimately can bring about critical reflection and change.

When discussing TEPs, Cárdenas (2009) argues for complementary use of the models proposed by Wallace (1991) and Freeman (1991). On the one hand, Wallace identifies three models: the craft model based on the imitation of what experts do, the applied science model based on practical application of the theories of scholars, and the reflective model based on an ongoing construction and interpretation of knowledge and practice. Freeman, on the other hand, avows that teacher education can opt for three proposals: teaching as doing (behavioristic development of skills), teaching as thinking and doing (cognitivistic use of what teachers know), and teaching as knowing what to do (interpretative decision- making based on knowledge and reflection). Following Freeman, Cárdenas maintains the parallel use of all the models is necessary if EFL TEPs are to aid TEs and STs in undergoing interteaching, a movement towards effective, creative and self-sufficient practice from stages of dependence, information reception, and guidance (See Freeman, 1991). See the following diagram of the do- mains and models proposed by Richards, Wallace and Freeman.

It seems reasonable to assume that Colombian EFL TEPs should be committed to the methodical development and harmonious integration of ALL the domains and models proposed by Wallace and Freeman. Regrettably, most of these programs still are not appropriate spaces for cooperation, reflection, and transformation since, according to González and Sierra (2005), EFL TEPS remain based on models of training and education in which local realities and knowledge are displaced by colonial and utilitarian postures. Furthermore, as explained by González and Sierra, not only are there financial limitations in education that devalue the development of FL teachers, there also is a lack of possibilities to be part of innovation in the Colombian educational system. One possible alternative to change this situation or, at least, to alleviate it, is the systematic and careful implementation of reflective teaching in TEPs. Such implementation, however, calls for more than simply having more research classes in the syllabi or including research-oriented guidelines in the curricula. The next section will elaborate on this point.

\section{Reflective Teaching in EFL Teacher Education Programs}

Richards (1990, p. 5) regards reflective teaching as conscious recall and examination of a

Figure 1. Domains and Models in EFL Teacher Education Programs

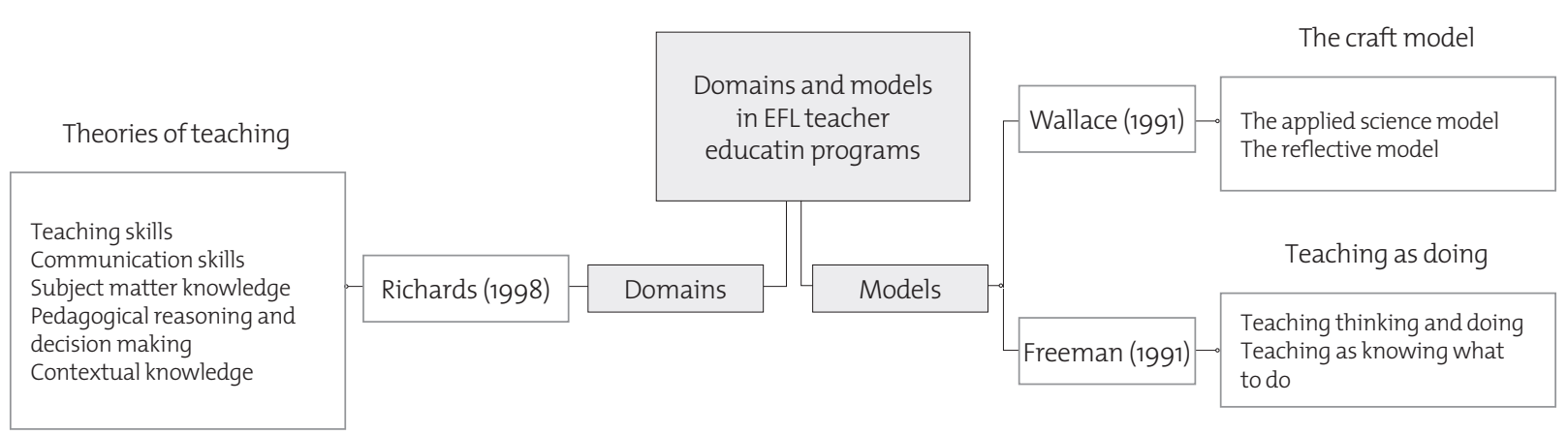


past experience as a basis for evaluation and decision-making, and as a source for planning and action. For her part, Pennington (1992, p. 47) defines reflective teaching as deliberating on experience in such a way that reflection can be viewed as both the input for and the output of development. More recently, Rezza (2007) stated that reflective teaching should not be viewed as a simple model whereby a solution is worked out for a problem without addressing the underlying causes of the problem. Rather, explains Rezza, reflective teaching examines the underlying assumptions and becomes a useful model to understand the interaction of dispositions (being), practice (doing), and professional knowledge (knowing).

Despite this multiplicity of definitions, Farrell (1998) identifies five major approaches to the study of reflective teaching: technical rationality, reflection-in-action, reflectionon-action, reflection-for-action, and action research. Each, in different ways, helps teachers to improve their educational perspectives. In his opinion, technical rationality examines teaching behavior and skills after an event, such as a class; reflection-in-action is concerned with thinking about what we are doing in the classroom, while we are doing it; reflectionon-action deals with thinking back on what we have done to discover how our knowing-in- action may have contributed to an unexpected action; reflection-for-action is proactive in nature, since reflection is undertaken to guide futureaction; and action research is self-reflective inquiry about craft-knowledge values of teaching that hold in place our habits when we are teaching. According to Farrell, integrating these approaches can help teachers to improve their educational perspectives.

In a similar vein, Pickett (2004) maintains reflective teaching compels STs and TEs to look at the reasons and theories behind their practices and forces them to examine factors such as beliefs and assumptions about learning, students' needs, and teachers' relationship with the larger community. In looking at the process of reflection in teaching, Pickett claims quite a lot of authors have discussed different, but complementary cycles, stages, and elements that facilitate active, persistent, and careful consideration of beliefs and/or practices in light of the grounds that support them and the further consequences to which they lead (See Canning, 1991). To Pickett, the cy cles, stages, and elements must help STs and TEs discuss what they do, what their actions mean, how they came to be the way they are, how they might do things differently, and how they will put new information into practice. See the table below.

Table 1. Reflective Teaching: Phases, Stages, and Levels

\begin{tabular}{|c|c|c|}
\hline Phases in reflective teaching & Stages of & evels c \\
\hline $\begin{array}{l}\text { Khelifa (2009) talks about six phases of } \\
\text { reflective teaching: } \\
\text { 1. Awareness: consists of problem } \\
\text { recognition initiated when teachers } \\
\text { notice a certain pattern in student } \\
\text { behavior; } \\
\text { 2. Critical inquiry: begins when teachers } \\
\text { analyze what happens and goes } \\
\text { wrong in class. } \\
\text { Consultation: teachers shift their } \\
\text { focus to brainstorming and problem- } \\
\text { solving. } \\
\text { Consideration and selection: teachers } \\
\text { choose a solution from a list of } \\
\text { alternates. } \\
\text { Implementation: a time for teachers } \\
\text { to try out a solution or strategy to } \\
\text { solve or improve a problem. } \\
\text { Evaluation: teachers assess the effects } \\
\text { of the implemented changes. }\end{array}$ & $\begin{array}{l}\text { Bartlett (1990) presents five stages } \\
\text { of reflective teaching: } \\
\text { 1. Mapping: asks the question: } \\
\text { What do I do as a teacher? } \\
\text { 2. Informing: poses the question: } \\
\text { What do I intend to accom- } \\
\text { plish? } \\
\text { Contesting: asks the question: } \\
\text { How did I come to be this } \\
\text { way and how was it possible } \\
\text { for my present view to have } \\
\text { emerged? } \\
\text { Appraising: poses the } \\
\text { question: How might I teach } \\
\text { differently? } \\
\text { Acting: asks the question: } \\
\text { What and how shall I now } \\
\text { teach? }\end{array}$ & $\begin{array}{l}\text { Ballard and McBride (2010) argue about } \\
\text { three elements of reflective teaching: } \\
\text { 1. Technical rationality: deals with } \\
\text { the practical application of } \\
\text { educational knowledge and basic } \\
\text { curriculum principles (e.g. Are the } \\
\text { students on task?); } \\
\text { 2. Practical action: occurs when } \\
\text { the teacher strives to clarify } \\
\text { assumptions and predispositions, } \\
\text { while assessing educational } \\
\text { consequences (e.g. How are goals } \\
\text { being met?) } \\
\text { Critical reflection: the teacher } \\
\text { is concerned with the worth } \\
\text { of knowledge and social } \\
\text { circumstances to students (e.g. } \\
\text { Was the content important to the } \\
\text { students?) }\end{array}$ \\
\hline
\end{tabular}


Following Khelifa, Bartlett, Ballard and McBride, EFL TEPs could establish and demand an observe-interpret-question-transform philosophy of teaching and learning. Such a philosophy would ask STs and TEs to characterize, explain, discuss, and innovatively insert their practices, processes, experiences, and, ultimately, their realities in a permanent, systematic and rigorous way. In other words, EFL TEPs should have their members describe what they do, clarify the meaning of their decisions and actions, seek alternatives or possibilities, and implement changes or innovations. Yet, how can an observe-interpret-question-transform philosophy be implemented in Colombian EFL TEPs? Richards (1991), Brookfield (1995), Gimenez (1999), and Farrell (2008) propose basic ideas for STs and TEs to develop a deeper understanding of their classroom experiences, to assess their professional growth, to build informed decision-making skills, and to become proactive and confident individuals. See the table below.

\section{Table 2. Reflective Teaching: Practical Ideas}

\begin{tabular}{|c|c|}
\hline Richards (1991) & $\begin{array}{l}\text { Peer observation: opportunities for collaborative reflection on teaching practices. } \\
\text { Written accounts of experiences (self-reports, autobiographies, and journals): a regular assessment of what } \\
\text { teachers do and experience in class. } \\
\text { Recording lessons: accounts of the moment-to-moment teaching processes. }\end{array}$ \\
\hline $\begin{array}{l}\text { Brookfield } \\
\text { (1995) }\end{array}$ & $\begin{array}{l}\text { The autobiographical lens (teaching journals, evaluations): a perspective that encourages teachers to } \\
\text { appreciate the paradigmatic assumptions framing their actions. } \\
\text { The students'lens (student journals, student focus groups or interview responses): a perspective that } \\
\text { allows teachers to check what teaching behaviors need be adjusted or can be harnessed for greater } \\
\text { impact. } \\
\text { The peers'/colleagues'lens (mentoring, seminar/workshop participation, peer review): a perspective that } \\
\text { helps teachers to notice hidden habits in their teaching practice or to design innovative solutions to } \\
\text { teaching problems. } \\
\text { The theoretical literature lens (articles, books, research groups): a perspective that enables teachers to } \\
\text { understand the link between their teaching struggles and broader political and educational processes. }\end{array}$ \\
\hline $\begin{array}{l}\text { Gimenez } \\
\text { (1999) }\end{array}$ & $\begin{array}{l}\text { Participating in language learning experiences using written records to re-think forgotten issues. } \\
\text { Remembering past experiences through autobiographies to identify factors that are important to them. } \\
\text { Carrying out action research or exploratory research to gain a systematic understanding of the language } \\
\text { classroom. }\end{array}$ \\
\hline Farrell & $\begin{array}{l}\text { Action research allows teachers to analyze their realities in order to improve instruction. } \\
\text { Teaching journals help teachers to monitor their own practices. } \\
\text { Teacher development groups assist teachers in reflecting on content and methodologies. }\end{array}$ \\
\hline
\end{tabular}

Based on Richard, Brookfield, Gimenez, and Farrell, EFL TEPs should have STs and TEs carry out reflective endeavors during all academic courses, course work, and content. Literature, peers (classmates and colleagues), and settings can be used initially as starting points to identify challenging factors and issues that affect teaching and learning. Observations, written accounts, audio and video recordings, and development groups then can be used to notice, monitor, and understand underlying assumptions, repeated actions, and hidden agendas. Lastly, STs and TEs can do exploratory, interpretative, and critical research projects to transform educational practices and to generate pertinent knowledge. To sum up, reflective endeavors in TEPs should involve all their members, make use of different methods, and facilitate the construction of theory. One way to consistently promote reflection in EFL teaching is by infusing inquiry throughout EFL TEPs. This is to say that implementing research-oriented guidelines in the curriculum or opening research-based courses in the syllabus is not enough. What EFL TEPs really need is to be committed to living and 
exercising inquiry systematically in all their formative processes and academic practices. See the following discussion on this point.

\section{Inquiry in EFL Teacher Education Programs}

Inquiry is a dynamic process of being open to wonder and puzzlement and coming to know and understand the world. As such, it is a stance that pervades all aspects of life and is essential to the way knowledge is created. Inquiry is based on the belief that understanding is constructed in the process of people working and conversing together as they pose and solve the problems, make discoveries and rigorously test the discoveries that arise in the course of shared activity (Galileo Educational Network, 2009). In a similar vein, Justice, Rice, Warry, Inglis, Miller and Sammons (2007) say inquiry refers both to the process of seeking knowledge and new understanding, as well as to a method of teaching grounded in this process. To them, the inquiry process is about discovery and systematically moving from one level of understanding to another, higher level.

As Broderick and Hong (2005) explain, when teachers talk about inquiry, they refer to observing thinking and learning, documenting their observations and analyzing them to develop research questions focused on what to study with and about students, in order to extend their already developing knowledge. For her part, Sharkey (2009) understands inquiry as a stance that emphasizes teacher learning as a lifelong process of posing and pursuing questions pertinent to local contexts. She maintains TEPs need to infuse inquiry into all aspects of the curriculum so STs and TEs can generate local knowledge, envision and theorize their practice, and interpret and interrogate the theory and research of others. By methodically inculcating inquiry, asserts Sharkey, TEPs can become communities of praxis:

“... a professional learning community, operating on principles of collaboration, inquiry and critical reflection committed to praxis as means of transforming educational practices and policies. A community of praxis enacts an inquiry as stance philosophy on a sustained basis, with fluid membership, and multiple opportunities and forms of participation." (p. 142).

Similarly, Fichtman and Yendol-Hoppey (2009) define teacher inquiry as systematic, intentional study of one's own professional practice. In other words, teacher inquiry consists of becoming part of a larger struggle in education-the struggle to better understand, inform, shape, reshape, and reform standard school practice. As a result, teacher inquiry differs from traditional professional development for teachers, which has typically focused on the expertise of an outside "specialist" being shared with a group of teachers. For their part, Cochran-Smith, Barnatt, Friedman, and Pine (2009) say the conceptual umbrella of practitioner inquiry refers to a variety of educational research approaches, methods, and purposes, including action research, teacher research, selfstudy, and narrative inquiry. To them, practitioner inquiry uses intentional and systematic ways of gathering and recording info rmation and documenting experiences; this, in turn, makes it possible for practitioner researchers to produce richly detailed and unusually insightful analyses of teaching and learning from the inside.

The main point being made here is that, if EFL teacher education programs are to achieve and develop independence, creativity, critical reflection and change, STs and TEs need to have systematic opportunities and space (not just courses and guidelines) to read, examine, and evaluate their realities and practices through continuing inquiry. Now, how exactly can EFL TEPs permeate reflection throughout the entire professional education component and support the necessary conditions for the creation and maintenance of what Sharkey calls a community of praxis? The next section develops this issue.

\section{Reflection-Oriented Strategies for EFLTeacher Education}

Calderhead and Gates (1993) highlight several issues that need to be considered when infusing reflection into professional education of teachers. For instance, they indicate reflection in teacher education involves values, attitudes and beliefs, as well as cognitive skills. They also 
suggest there is a developmental process in becoming reflective that starts with building up a vocabulary for talking and writing about practice and ends with using research and academic theories to appraise classroom practice and its context. When discussing aims, Calderhead and Gates maintain that TEPs based on notions of reflective practice should strive to:

- $\quad$ enable STs and TEs to analyze, discuss, evaluate and change their own practice by adopting an analytical approach towards teaching and learning;

- $\quad$ encourage them to take greater responsibility for their own professional growth and autonomy;

- facilitate an enhancement of theories of educational practice; and

- $\quad$ promote an understanding and development of a principled basis for classroom work.

For her part, Kagan (1992 as cited in Rideout \& Koot, 2009) recommends four guidelines for TEPs to improve reflective abilities: procedural knowledge, self-reflection, knowledge of pupils, and cognitive dissonance. To Kagan, procedural knowledge should be emphasized over theoretical knowledge by promoting routines that help to understand what works and why it works. Self-reflection, states Kagan, should be augmented, since it opens opportunities to analyze beliefs, behaviors, and image of self. TEPs should allow for sufficient knowledge of pupils (their aptitudes, interests, and problems) through a combination of extended practicums and structured "research projects" that allow for analyses of classroom realities. Finally, cognitive dissonance needs to be amplified in TEPS so pre- and in-service teachers can determine whether they need to change or to adjust their understanding of teaching and learning. Such reflective-oriented guidelines can, asserts Kagan, provide STs and TEs with a framework in which they can learn to respond thoughtfully to EFL challenges and experiences.

More recently, Korthagen, Loughran, and Russell (2006 as cited in Rideout \& Koot, 2009) identify several principles of effective teacher education grounded in reflection: meaningful collaboration, supporting learning and teaching communities, the presence of cohort groups, and writing tasks and research. Firstly, meaningful collaboration among all involved parties is required to develop good practice that responds properly to competing and conflicting demands of the classroom. Secondly, TEPs should build supporting learning and teaching communities that can facilitate close working relationships and ensure professional growth. Thirdly, Korthagen et al. maintain the presence of cohort groups is a strength within TEPs, not only because they give a sense of public accountability, but also because they facilitate psy chological and personal enablement. Fourthly, writing tasks and research to foster self-reflection are important, because anecdotes and studies allow for a confrontation of preconceptions and opening to new views and understandings. According to Korthagen et al., when reflection-enhancing practices are prominent,TEPS are more likely to generate an educational community atmosphere where STs and TEs can learn and teach through interaction and cooperation.

In Colombia, González and Quinchía (2003) claim EFL TEPs should have four main focuses to ensure professional growth: (1) knowledge of local realities, (2) command of the language, (3) broad experience in teaching EFL, and (4) experience in research. These focuses can help STs and TEs be sensitive to the particular conditions of the sociocultural milieu in which teaching andlearningtake place; achieve high levels of language proficiency; teach English in different settings and across different age groups; and explore school environments and create knowledge in the discipline. González (2003) also states TEPs should help STs and TEs to develop their potential in three major domains: EFL teachers as workers able to participate in the decisions made at schools, EFL teachers as instructors equipped with new and effective teaching techniques to empower students, and EFL teachers as learners capable of constructing and participating in collaborative networks. More concretely, González (2007) proposes EFL TEPs should be constructed with the following characteristics: (1) application of a post-method framework based on parameters of particularity, practicality, and possibility, and macro strategies for language teaching; (2) practice of peripheral knowledge construction; 
(3) establishment of adequate communication with local scholars and policy makers; and (4) acceptance of counter-discourses and a critical theory of teacher education. By having these focuses, domains, and characteristics, EFL TEPs can search for new agendas for professional growth based on agreements emerging from reflecting on and transforming everyday realities. Ultimately, they can be committed to the deconstruction of colonial practices and the construction of new local discourses that respond to the educational needs and interests of STs, TEs and formative agendas.
It seems reasonable that EFL TEPs should consider it particularly important to make reflective teaching a central part of their everyday processes and spaces, not just merely part of syllabus reform and curriculum innovation. In other words, observing, questioning, describing, taking notes, interpreting, reflecting, planning, acting, and writing are competences to be included gradually, as a natural routine in the daily life of EFL STs and TEs. Ideally, through reflection, EFL TEPs not only can create advanced knowledge on the basis of practical

Figure 2. Reflection in EFL TEPs

\begin{tabular}{|c|c|c|c|c|c|c|}
\hline & & & REFLECTIVE EFL TEPS & & & \\
\hline AIMS & GUIDELINES & PRINCIPLES & $\begin{array}{c}\text { CORE KNOWLEDGE } \\
\text { BASE }\end{array}$ & FOCUSES & DOMAINS & CHARACTERISTICS \\
\hline $\begin{array}{l}\text { Help STs and Tes } \\
\text { become: } \\
\text { • } \quad \text { Critical } \\
\text { consumers of } \\
\text { information } \\
\text { Creative } \\
\text { producers of } \\
\text { knowledge } \\
\text { Informed } \\
\text { participants } \\
\text { in education } \\
\text { context } \\
\text { Active agents } \\
\text { in reflective } \\
\text { inquiry }\end{array}$ & $\begin{array}{l}\text { Procedural } \\
\text { knowledge to } \\
\text { understand } \\
\text { what works and } \\
\text { why it works } \\
\text { - Self-reflection to } \\
\text { analyze beliefs, } \\
\text { behaviors, and } \\
\text { self-image } \\
\text { Sufficiente } \\
\text { knowledge } \\
\text { of students } \\
\text { to allow for } \\
\text { analyses of } \\
\text { classroom } \\
\text { realities } \\
\text { Cognitive } \\
\text { dissonance to } \\
\text { change or adjust } \\
\text { understanding } \\
\text { ofteaching and } \\
\text { learning }\end{array}$ & $\begin{array}{l}\text { Meaningful } \\
\text { collaboration to } \\
\text { develop good } \\
\text { practice } \\
\text { Supporting } \\
\text { learning and } \\
\text { teaching } \\
\text { communities } \\
\text { to facilitate } \\
\text { relationships } \\
\text { The presence of } \\
\text { cohort groups } \\
\text { to facilitate } \\
\text { psychological } \\
\text { and personal } \\
\text { enablement } \\
\text { writing tasks } \\
\text { and research } \\
\text { to foster self- } \\
\text { relfection }\end{array}$ & $\begin{array}{l}\text { Theories of } \\
\text { teaching: } \\
\text { theoretical } \\
\text { bases } \\
\text { Teaching } \\
\text { skills: essential } \\
\text { dimensions } \\
\text { of teacher's } \\
\text { repertoire } \\
\text { Communication } \\
\text { skills: language } \\
\text { proficiency } \\
\text { Subject matter } \\
\text { knowledge: } \\
\text { specialized } \\
\text { disciplinary } \\
\text { knowledge } \\
\text { Pedagocial } \\
\text { reasoning and } \\
\text { decision making } \\
\text { cognitive and } \\
\text { problem-solving } \\
\text { skills } \\
\text { Contextual } \\
\text { knowledge: } \\
\text { educational } \\
\text { and linguistic } \\
\text { policies together } \\
\text { with familiarity } \\
\text { of students } \\
\text { programs, and } \\
\text { institutions }\end{array}$ & $\begin{array}{ll}\text { - } & \text { Knowledge of } \\
\text { local realities } \\
\text { - } \quad \text { Command of } \\
\text { the language } \\
\text { Broad } \\
\text { experiences in } \\
\text { teaching EFL } \\
\text { experience in } \\
\text { research }\end{array}$ & $\begin{array}{ll}\text { - } & \text { EFL teachers as } \\
\text { participative } \\
\text { workers of } \\
\text { schools } \\
\text { EFL teachers } \\
\text { as instructors } \\
\text { equipped } \\
\text { with effective } \\
\text { teaching } \\
\text { strategies } \\
\text { EFL teachers } \\
\text { as learners in } \\
\text { collaborative } \\
\text { networks }\end{array}$ & $\begin{array}{l}\text { Communities } \\
\text { of praxis } \\
\text { commited to } \\
\text { transforming } \\
\text { educational } \\
\text { practices and } \\
\text { policies } \\
\text { An observe- } \\
\text { interpret- } \\
\text { question- } \\
\text { transform } \\
\text { philosophy } \\
\text { of education } \\
\text { adopted to } \\
\text { promote } \\
\text { professional } \\
\text { development } \\
\text { Application of } \\
\text { a postmethod } \\
\text { framework } \\
\text { Practice of } \\
\text { peripheral } \\
\text { knowledge } \\
\text { construction } \\
\text { Adequate } \\
\text { communication } \\
\text { with scolars and } \\
\text { policy makers } \\
\text { Acceptance } \\
\text { of counter- } \\
\text { discourses and } \\
\text { a critical theory } \\
\text { of teacher } \\
\text { education }\end{array}$ \\
\hline
\end{tabular}


experience, they also can improve the context or conditions in which practice takes place. For a summary of what reflective EFL TEPs should have and do, see the figure below.

\section{Conclusion}

The multiplicity of compulsory FL policies and reforms makes it difficult for STs and TEs to qualify their pedagogical practice and to develop strategies for critical reflection and change. However, conceiving how this crucial qualification might be done can start by implementing reflective teaching in EFL TEPs in a methodical and deliberate way, so EFL STs and TEs can construct local knowledge, examine their actions, and question the theory of others. Ultimately, reflective teaching can allow the EFL community to learn to construct its own particular theories from its everyday practice and reality.
Nevertheless, promoting teachers' reflection is, as Jerez (2008) maintains, a multifaceted and long-drawn-out process, since it demands critical thought and self-direction, coupled with personal knowledge and self-awareness. Similarly, explains Jerez, there are other conditions and limitations (beliefs, attitudes, established practices, organizational obstacles) that do not allow teachers to change from one day to the next. Despite the difficulties EFL TEPs may encounter along the way, assuming a reflective teaching philosophy, infusing systematic inquiry, and advocating for communities of praxis in all their processes and actions (not just in courses and guidelines) are necessary actions if the Colombian EFL teacher community is to have a voice and force of its own.

\section{References}

Adler, S. (2004). "Introduction." In S. Adler (Ed.), Critical issues in social studies. Teacher education (pp. 1-7). USA: Information Age Publishing Inc.

Agray, N. (2008). “¿Qué le pide hoy la sociedad colombiana a un profesor de lenguas extranjeras?" Signo y Pensamiento, 27 (53), 352-357. Retrieved April 2, 2011 from http://recursostic.javeriana.edu.co/cyl/syp/components/com_booklibrary/ebooks/23\%20Agray53.pdf.

Ballard, K. \& McBride, R. (2010). “Promoting pre-service teacher reflectivity. Van Manen may represent a viable model." Physical Educator, 67 (2), 58-73. Retrieved April 2, 2011 from http://www.freepatentsonline.com/article/Physical-Educator/226474622.html.

Bartlett, L. (1990). “Teacher development through reflective teaching." In J. Richards \& D. Nunan (Eds.), Second language teacher education (pp. 202-214). Cambridge: Cambridge University Press.

Broderick, J. \& Hong, S. (2005). “Inquiry in early childhood teacher education: Reflections on practice." The Constructivist, 16 (1). Retrieved April 2, 2011 from http://www.odu.edu/educ/act/journal/vol16no1/broderick.pdf.

Brookfield, S. (1995). Becoming a critically reflective teacher. San-Francisco: Jossey-Bass.

Burns, A. (2005). "Research and teacher education: Some distinctions." E-Journal for Researching Teachers. Retrieved June 27,2011 from http://www.culi.chula.ac.th/e-Journal/bod/Anne\%2oBurns.pdf.

Caicedo, Y. (2008). "Tendencias curriculares y formación de docentes: Hacia una reflexión sobre nuestro quehacer como docentes en las facultades de educación." Cuadernos de Psicopedagogía, 5, 35-44. Retrieved June 27, 2011 from http://aplica.uptc.edu.co/Publicaciones/CuadernosPsicopedagogia/Documents/N5_Articulo3.pdf. 
Calderhead, J. \& Gates, P. (1993). Conceptualizing reflection in teacher development. Great Britain: Burgess Science Press.

Calvo, G., Rendón, D. \& Rojas, L. (2004). Un diagnóstico de la formación docente en Colombia. Bogotá: IESALC, UNESCO. Retrieved June 29, 2011 from http://www.lpp-buenosaires.net/documentacionpedagogica/ArtPon/PDF_ArtPon/ Formacion\%2odocente\%2oen\%2oColombia.pdf.

Canning, C. (1991). "What teachers say about reflection." Educational Leadership, 48 (6), 18-21. Retrieved January 23, 2011 from http://www.ascd.org/ASCD/pdf/journals/ed_lead/el_199103_canning.pdf.

Cárdenas, R. (2009). “Tendencias globales y locales en la formación de docentes de lenguas extranjeras.” íKALA: Revista de Cultura y Lenguaje, 14 (22), 71-106. Retrieved January 23, 2011 from http://aprendeenlinea.udea.edu.co/revistas/index.php/ikala/article/view/2634/2121.

Cochran-Smith, M., Barnatt, J., Friedman, A. \& Pine, G. (2009). "Inquiry on inquiry: Practitioner research and student learning." Action in Teacher Education, 31 (2), 17-32. Retrieved April 2, 2011 from http://tne.bc.edu/documents/INquiryonlnquiry.pdf.

Cochran-Smith, M. \& Zeichner, K. (2009). Studying teacher education. The report of the AERA panel on research and teacher education. USA: Lawrence Erlbaum Associates, Inc., Publishers.

Erazo-Jiménez, M. (2009). "Práctica reflexiva como estrategia de desarrollo profesional: Presencia y estructura en reuniones docentes." Educación y Educadores, 12 (2), 47-74. Retrieved June 28, 2011 from http://educacionyeducadores.unisabana.edu.co/index.php/eye/article/view/1485/1654.

Farrell, T. (2008). "Reflective practice in the professional development of teachers of adult English language learners." CAELA Network Brief [online]. Retrieved April 2, 2011 from http://www.cal.org/caelanetwork/resources/reflectivepractice.html.

Farrell, T. (1998). "Reflective teaching: Principles and practices." English Teaching Forum, 36 (4). Retrieved January 23, 2011 from http://eca.state.gov/forum/vols/vol36/no4/p1o.htm.

Feiman-Nemser, S. (1990). Conceptual orientations in teacher education. Issue Paper 90-2, National Center for Research on Teacher Education, Michigan State University. Retrieved April 2, 2011 from http://ncrtl.msu.edu/http/ipapers/html/pdf/ipgo2.pdf.

Fichtman, N. \& Yendol-Hoppey, D. (2009). The educator's guide to classroom research. Learning to teach and teaching to learn through practitioner inquiry. USA: Corwin Press.

Freeman, D. (1991). “Three views to teachers' knowledge." IATEFL Teacher Development Newsletter, December, 1-4.

Galileo Educational Network (2009). What is inquiry? Teachers, Articles. Calgary: University of Calgary. Retrieved April 2, 2011 from http://www.galileo.org/inquiry-what.html. 
Gimenez, T. (1999). "Reflective teaching and teacher education contributions from teacher training." Linguagem \& Ensino, 2 (2), 129-143.Retrieved February 23, 2011 from http://rle.ucpel.tche.br/php/edicoes/v2n2/F_gimenez.pdf.

González, A. (2009). “On alternative and additional certifications in English language teaching:The case of Colombian EFL teachers' professional development." ÍKALA: Revista de Lenguaje y Cultura, 14 (22), 183-209. Retrieved February 232011 from http://aprendeenlinea.udea.edu.co/revistas/index.php/ikala/article/view/2635/2122.

González, A. (2007). "Professional development of EFL teachers in Colombia: Between colonial and local practices”. IKALA: Revista de Lenguajey Cultura, 12 (18), 309-332. Retrieved February 23, 2011 from http://aprendeenlinea.udea.edu.co/revistas/index.php/ikala/article/view/2722/2175.

González, A. (2003). "Who is educating EFL teachers: A qualitative study of in-service in Colombia." IKALA:Revista de Lenguaje y Cultura, 8 (14), 153-172. Retrieved September 7, 2010 from http://aprendeenlinea.udea.edu.co/revistas/index.php/ikala/article/view/3183/2947.

González, A. \& Quinchía, D. (2003). “Tomorrow's EFL teacher educators." Colombian Applied Linguistics Journal, 5 , 86-104. Retrieved September 7, 2010 from http://calj.udistrital.edu.co/pdf_files/App_2003/Art5.pdf.

González, A. \& Sierra, N. (2005). “The professional development of foreign language teacher educators: Another challenge for professional communities." IKALA: Revista de Lenguaje y Cultura, 10 (16), 11-29. Retrieved September 7, 2010 from http://aprendeenlinea.udea.edu.co/revistas/index.php/ikala/article/view/3049/2824.

Jerez, S. (2008). “Teachers' attitudes towards reflective teaching: Evidences in a professional development program (PDP).” PROFILE Issues in Teachers'Professional Development, 10, 91-111. Retrieved February 23, 2011 from http://www.scielo.org.co/pdf/prf/n10/n10ao6.pdf.

Johnson, K. (2009). “Trends in second language teacher education.” In A. Burns \& J. Richards (Eds.), Second language teacher education (pp. 20-29). Cambridge: Cambridge University Press.

Justice, C., Rice, J., Warry, W., Inglis, S., Miller, S. \& Sammon, S. (2007). “Justice, inquiry in higher education: Reflections and directions on course design and teaching methods." Innovative Higher Education, 31, 201-214. Retrieved April 2, 2011 from http://faculty.njcu.edu/fmoran/gscc/justiceetal.pdf.

Kagan, D. (1992). “Professional growth among preservice and beginning teachers." Review of Educational Research, $62(2), 129-169$.

Khelifa, M. (2009). "Reflective practice in a cross-cultural university setting: A theoretical model." Teaching in Higher Education:GulfPerspectives, 6 (1). Retrieved April 2, 2011 from http://www.zu.ac.ae//the//theo6_01_01_khelifa.htm.

Korthagen, F., Loughran, J. \& Russell,T. (2006). “Developing fundamental principles for teacher education programs and practices." Teaching and teacher education: An international journal of research and studies, 22 (8), 1020-1041. 
Loughran, J. (2006). Developing a pedagogy of teacher education. Understanding teaching and learning about teaching. New York: Routledge Taylor \& Francis group.

Muñoz, J., Quintero, J. \& Munévar, Raúl. (2002). "Experiencias en investigación-acción-reflexión con educadores en proceso de formación." Revista Electrónica de Investigación Educativa, 4 (1). Retrieved July 27, 2011 from http://redie.uabc.mx/vol4no1/contenido-munevar.html.

Pennington, M. (1992). "Reflecting on teaching and learning:A development focus for the second language classroom." In J. Flowerdew, M. Brock, and S. Hsia (Eds.), Perspectives on second language classroom teacher education (pp. 47-65). Kowloon: City Polythenic of Hong Kong.

Pickett, A. (2004). Reflective teaching practices and academic skills instruction [online]. Retrieved January 14, 2011 from http://documents.cms.k12.nc.us/dsweb/Get/Document-9334/.

Rezza, M. (2007). "From reflective teaching to effective learning: A new class order." Iranian Journal of Language Studies (IJLS), 1 (2), 89-102. Retrieved January 14, 2011 from http://www.ijls.net/volumes/volumerissue2/taghilou1.pdf.

Ricento, T. (2006). "Theoretical perspectives in language policy: An overview." In T. Ricento (Ed.), An introduction to language policy. Theory and method (pp.3-9). UK: Blackwell Publishing Ltd.

Richards, J. (1998). Beyond training. Cambridge: Cambridge University Press.

Richards, J. (1991). “Towards reflective teaching." The teacher Trainer: A Practical Journal for those who Train, Mentor, and Educate TESOL teachers, 5 (3), 4-8. Retrieved January 14, 2011 from http://www.tttjournal.co.uk/uploads/File/back_articles/Towards_Reflective_Teaching.pdf.

Richards, J. (1990). “Beyond training: Approaches to teacher education in language teaching." Language Teacher, 14 (2), $3-8$.

Rideout, G. \& Koot, R. (2009). "Reflective, humanistic, effective teacher education: Do principles supported in the deans' accord make a difference in a program outcomes?" Canadian Journal of Education, 32 (4), 927-956. Retrieved April 2, 2011 from www.csse.ca/CJE/Articles/FullText/CJE32-4/CJE32-4-RideoutKoot.pdf.

Sharkey, J. (2009). "Can we praxize second language teacher education? An invitation to join a collective, collaborative challenge." ÍKALA: Revista de Lengua y de Cultura, 14 (22), 125-150. Retrieved September 7, 2010 from http://aprendeenlinea.udea.edu.co/revistas/index.php/ikala/article/view/2635/2122.

Shohamy, E. (2006). Language policy: Hidden agendas and new approaches. London and New York: Routledge.

UNESCO (1990). Innovations and initiatives in teacher education in Asia and the Pacific region. Bangkok: UNESCO Principal Regional Office for Asia and the Pacific. Retrieved January 14, 2011 from http://www.unesco.org/education/pdf/412_35a.pdf. 
Vergara, O., Hernández, F. \& Cárdenas, R. (2009). "Classroom research and professional development." PROFILE Issues in Teachers' Professional Development, 11, 169-191. Retrieved June 27, 2011 from http://www.revistas.unal.edu.co/index.php/profile/article/viewFile/10557/11017.

Vieira, I. \& Moreira, M. A. (2008). "Reflective teacher education towards learner autonomy: building a culture of possibility." In M. Raya \& T. Lamb (Eds.), Pedagogy for Autonomy in Language Education: Theory, practice and teacher education (pp. 266-282). Dublin: Authentik.

Villegas-Reimers, E. (2002). Teacher Preparation, International Perspective. Encyclopedia of Education [online]. Retrieved February 23, 2011 from http://www.ency clopedia.com/doc/1G2-3403200613.html.

Wallace, M. (1991). Training foreign language teachers. A reflective approach. Cambridge: CUP.

Zambrano, L. \& Insuasty, E. (2009). “Assessing student-teachers' perceptions about the implementation of reflective teaching tools in the practicum." Hechos y Proyecciones del Lenguaje, 18, 39-54. Retrieved June 23, 2011 from http://editorial.udenar.edu.co/revistas/revistahpl/documentos/Vol18.pdf. 